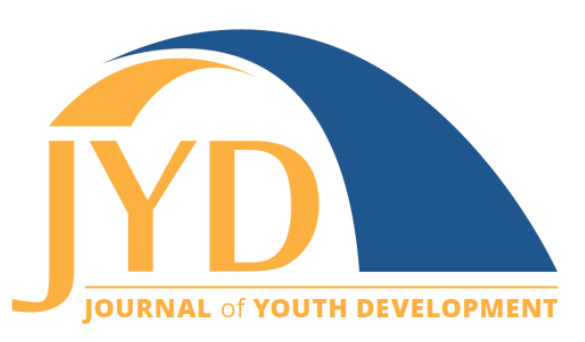

http://jyd.pitt.edu/ | Vol. 15 Issue 1 DOI 10.5195/jyd.2020.807 | ISSN 2325-4017 (online)

\title{
Supporting the Out-of-School Time Workforce in Fostering Intentional Social and Emotional Learning
}

\author{
Jessica Zadrazil Newman \\ American Institutes for Research \\ jnewman@air.org
}

\begin{abstract}
Extensive research demonstrates that a qualified workforce is essential to out-of-school time program quality, which, in turn, is essential for positive youth development. Recently, the in-and out-of-school fields have witnessed an increase in attention to social and emotional learning practices and programs, yet less is known about how to support the adults who are engaged in the social and emotional learning process. A first step in supporting this workforce is to build the collective knowledge around what social and emotional learning is and what the practices are that support social and emotional development. We also believe there is a need to identify and describe the connection between what has been and what could be-that is, connecting youth development as a foundation for intentional social and emotional learning. We reviewed a selection of widely disseminated, research-based, practitioner-focused resources to identify the specific practices that promote social and emotional learning. This process elevated a set of 8 practices, which we delineated into 2 categories: foundational organizational practices and programmatic practices that support social and emotional development. In addition, we completed a comprehensive crosswalk of those practices with seminal youth development and out-of-school time resources to demonstrate the alignment and progression from youth development to social and emotional learning. This article describes the 8 social and emotional learning practices and highlights connections to foundational youth development practices. We conclude with a set of recommendations for the field leaders who must continue to support the workforce.
\end{abstract}

Key words: youth development, social and emotional learning, core knowledge and competencies

Extensive research (e.g., Eccles \& Gootman, 2002; Smith, et al., 2012; Vandell, Larson, Mahoney, \& Watts, 2015; Vandell, Reisner, \& Pierce, 2007) underpins our collective knowledge about quality youth development (YD) programming in out-of-school time (OST), which includes time spent before and after school, during the summer, and in other informal learning settings

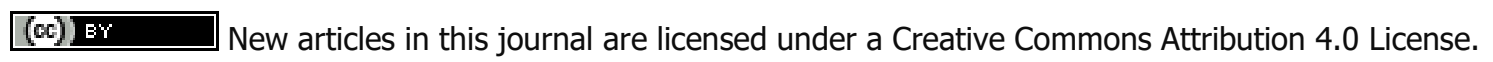
This journal is published by the University Library System, University of Pittsburgh and is cosponsored by the University of Pittsburgh Press. The Journal of Youth Development is the official peer-reviewed publication of the National Association of Extension 4-H Youth Development Professionals and the National AfterSchool Association. 


\section{Intentional Social and Emotional Learning}

(e.g., libraries, museums). It is now widely accepted, for example, that YD programs should ensure "physical and psychological safety, appropriate structure, opportunities to belong, positive social norms, support for efficacy and mattering, opportunities for skill building, integration of family, school, and community efforts, and nurturance and support" (Eccles \& Gootman, 2002, p. 90).

As an OST field, we have coalesced around what quality programming looks like in practice and how quality programs can benefit young people. That quality OST programming supports a litany of youth outcomes-from improved academic achievement and academic engagement, reductions in behavioral problems, and improved social functioning-is evident and wellresearched (Durlak, Weissberg, \& Pachan, 2010; Kataoka \& Vandell, 2013; Vandell et al., 2015; Vandell et al., 2007).

Gone are the days of equating OST programming with babysitting; we now know that simply providing a safe space-while still essential-is not always enough. The field has matured and, with that maturity, comes a refining and sharpening in scope and goals (Jones \& Doolittle, 2017). We understand the settings, activities, and practices that work best for youth who participate in OST programs. Moreover, research has demonstrated the need for systemic supports and qualified staff (Every Hour Counts, 2014; McElvain, Moroney, Devaney, Singer, \& Newman, 2014; Smith et al., 2012). As an OST field, we have responded accordingly by developing measures of process quality, articulating core knowledge and competencies, building systems for professional learning, and ensuring these are aligned with YD principles and practices that underpin our definitions of quality OST experiences.

\section{Supporting the Workforce in Implementing Quality OST Programming}

A qualified workforce is essential to OST program quality which, in turn, is essential for positive youth development (Eccles \& Gootman, 2002; Mahoney \& Warner, 2014; Smith, et al., 2012; Starr \& Gannett, 2017), yet the OST workforce has struggled with issues of turnover, compensation, and limited opportunities for professional learning (Starr \& Gannett, 2017). A national survey of 4,346 after-school workers revealed OST professionals have a range of education levels, backgrounds, and prior experiences and that opportunities for professional learning often vary greatly, with many OST professionals lacking formal education in the content areas they lead (Nee, Howe, Schmidt, \& Cole, 2006). It is this variety that, in many ways, is a strength of the OST workforce, as the diversity of thought that stems from each 


\section{Intentional Social and Emotional Learning}

person's lived experiences may foster creative, complex, and compassionate relationships in the OST setting. However, this variability also underscores the need to support the workforce in ensuring they have the basic knowledge and competencies that are essential when working with youth.

To better support the OST workforce, our field has witnessed both a litany of research-based calls to action (e.g., Cole, 2011; Moroney, 2016; Starr \& Gannett, 2017; Stone, Garza, \& Borden, 2004) and the development of resources in response to those calls. The National AfterSchool Association (NAA) developed the Core Knowledge and Competencies (CKCS) for Afterschool and Youth Development Professionals in 2011, for example, to address the needs identified in the literature. The NAA CKCs present the knowledge, skills, and dispositions needed by OST professionals to provide high-quality YD programming to support the learning and development of children and youth (NAA, 2011). The NAA CKCs outline core knowledge (the expertise needed by professionals to work effectively with school-age children and youth) and competencies (concrete, observable, and achievable behaviors that establish standards of practice) in 10 content areas:

- child and youth growth and development;

- learning environments and curriculum;

- child/youth observation and assessment;

- interactions with children and youth;

- youth engagement;

- cultural competency and responsiveness;

- family, school, and community relationships;

- safety and wellness;

- program planning and development; and

- professional development and leadership.

NAA provided the foundation for decisions and practices carried out by staff in OST programs across the country by (a) defining what OST professionals needed to know and be able to do to offer quality OST programming for youth and (b) aligning professional learning opportunities to support staff development (Warner, Ham, \& Fenton, 2017). This is not to say that the NAA CKCS were the only resource in the field to move the OST workforce forward, however, the development of the national CKCs was instrumental in distilling what we know from extensive 
research and practice into a practical resource that OST professionals nationwide could use to transform their practice.

Since the development of the NAA CKCS in 2011, many statewide after-school networks (who often serve to facilitate much of the OST professional learning) have adopted or developed staff core competency guidance as well. And because the national CKCs are research-based, they are often aligned with quality standards (see American Institutes for Research, 2017) and continuous improvement processes (e.g., Smith, et al., 2012) and tools. ${ }^{1}$ The Youth Program Quality Intervention, for example, describes a pyramid of instructional quality that includes creating a safe and supportive environment with high levels of positive interaction and engagement (Smith, et al., 2012), and many of these elements align with the CKCs and serve as the guidepost for other resources for the OST workforce. There is room to improve, as there always will be, but there exist systemic supports and a unified understanding of quality YD as a foundation for OST programming.

In addition to the now consistent emphasis on quality YD programming in OST, there has also been a focus on the role OST programs can play in skill development through quality enrichment activities that promote collaboration, inquiry, and engagement (Durlak et al., 2010; Smith, et al., 2012) and complement school-day learning (McCombs, Whitaker, \& Yoo, 2017; McElvain et al., 2014; Partnership for Children and Youth, 2017). Because learning happens across multiple settings, and because learning includes academic, social, and emotional development (Aspen Institute National Commission on Social, Emotional, \& Academic Development, 2018), we are now witnessing a cross-field increase in attention to the process of social and emotional learning (SEL), including in OST. While we have made progress in supporting YD professionals in their implementation of high-quality OST programming, less is known about how to best support the OST workforce who endeavor to support (or are tasked with supporting) SEL (Hurd \& Deutsch, 2017).

\section{What is Social and Emotional Learning?}

The Collaborative for Academic, Social, and Emotional Learning ([CASEL]; n.d.) defines SEL as "the process through which children and adults acquire and effectively apply the knowledge,

\footnotetext{
${ }^{1}$ There exist several research-based OST program quality tools such as the David P. Weikart Center's Program Quality Assessment and the National Institute on Out-of-School Time's Assessment of Program Practices observation instrument. For an in-depth examination of assessments that measure program quality and serve to facilitate professional learning for the OST workforce, see Measuring Youth Program Quality (Yohalem \& Wilson-Ahlstrom, 2009) and the second edition of Ready to Assess (American Institutes for Research, 2019).
} 


\section{Intentional Social and Emotional Learning}

attitudes, and skills necessary to understand and manage emotions, set and achieve positive goals, feel and show empathy for others, establish and maintain positive relationships, and make responsible decisions" (para. 1). This definition is helpful in framing SEL as a process whereby adults and youth engage in practices that support the development of knowledge, attitudes, mindsets, and skills (what are often referred to, collectively, as "competencies"not to be confused with the NAA competencies described previously) that enable adults and youth to succeed personally and socially throughout life.

There are myriad frameworks and practical resources available that define SEL practice and articulate a set of social and emotional competencies. In fact, a recent review by Berg and colleagues (2017) endeavored to identify the alignment between social and emotional competency frameworks. In their search, Berg and colleagues cast a wide net which yielded 136 different frameworks. It is no wonder that OST professionals across the field may approach SEL from a variety of perspectives and feel like more support is needed.

In 2015, NAA conducted a SEL-related survey of its members. Findings suggested that programs and staff value and implement SEL practices yet many OST professionals do not feel knowledgeable talking about SEL. In addition, findings emphasized the need for additional training in SEL and access to more SEL-related resources, such as specific practice and activity ideas (Moroney, Singer, \& Newman, 2016). It is worth mentioning that the findings from this survey mirror principal surveys conducted by CASEL which suggest principals also value SEL but need more supports for implementation (DePaoli, Atwell, \& Bridgeland, 2017).

It has become apparent that, while OST professionals see SEL as critical, the OST workforce needs more support to be able to implement SEL practices intentionally and effectively. In response to the 2015 survey findings, NAA issued a call to action: "field leaders should allocate resources to build capacity and develop tools and materials so that practitioners will be equipped to implement high quality social and emotional learning practices" (Moroney, Singer, \& Newman, 2016). In the sections that follow, we describe our efforts (in response to NAA's call to action) to (a) better understand SEL practice in OST and (b) articulate a set of recommendations for supporting an SEL-focused OST workforce. 


\section{Supporting Intentional SEL Practice Across the OST Workforce}

In the last 5 years, the OST field has generated a plethora of SEL practice-focused resources. Given this influx of materials, we posited that a critical first step in supporting intentional SEL across the OST workforce was to take a step back and focus on building the collective knowledge around what SEL is and what it looks like in OST settings. This shared understanding could then drive future efforts around resource development and opportunities for professional learning, coaching, and technical assistance. We began our quest to identify a set of shared SEL practices with a search for research- and field-based resources that emphasized SEL practice. We searched both peer-reviewed and published literature as well as "grey literature" (e.g., nonpeer-reviewed resource guides, tools, handbook chapters from thought leaders and organizations in OST) to capture the breadth of resources that were most likely to be accessed and used by the OST workforce. The search for resources included relevant terms including but not limited to content terms (e.g., "social and emotional learning," "social-emotional learning," "SEL," "personal and social learning") in combination with OST setting terms (e.g., "afterschool," "out-of-school time," "OST", "informal learning") in search engines such as PsycINFO, JSTOR and ERIC, and Google Scholar. In addition to a formal search, experts in the field recommended additional sources to include in the review. We chose final sources for inclusion in the review based on recent publication dates (within the last 10 years) and the content of the resource; namely, that practices to support SEL were the focus.

As shown in Table 1, our search process yielded 11 resources for review. Ultimately, the search process was designed to be comprehensive; however, the knowledge base is rich, diverse, and ever-changing (indeed, new resources have emerged since the review process for this project began), and any search process has limitations. As such, the included resources represent an effort to review a range of resources and SEL practices. The exclusion of any given source is not intended to imply its lack of value to the field. Similarly, the inclusion of a source does not represent any evaluation of its methodologies or findings. 
Journal of Youth Development | http://jyd.pitt.edu/ | Vol. 15 Issue 1 DOI 10.5195/jyd.2020.807 Intentional Social and Emotional Learning

Table 1. Practices and Recommendations From Resources Selected for Review and Inclusion

\begin{tabular}{|c|c|}
\hline Resource & Practices \\
\hline $\begin{array}{l}\text { Social and emotional learning } \\
\text { practices: A self-reflection tool for } \\
\text { afterschool staff (Beyond the Bell, } \\
\text { 2015) }\end{array}$ & $\begin{array}{l}\text { Social Practices } \\
\text { - } \text { Youth-centered problem-solving } \\
\text { - } \text { Program staff language } \\
\text { - } \text { Responsibility and choice } \\
\text { Program Implementation Practices } \\
\text { - Cooperative/group learning } \\
\text { - Group discussions } \\
\text { - Self-reflection/assessment } \\
\text { - Balanced program activities } \\
\text { - Encouraging grit and persistence } \\
\text { - Competence-building (modeling, practicing, feedback, coaching) } \\
\text { Social and Emotional Competencies } \\
\text { - Self-awareness } \\
\text { - Self-management/emotion regulation } \\
\text { - } \text { - } \text { - Rocial awareness } \\
\text { - Responsible decision-making } \\
\text { - }\end{array}$ \\
\hline
\end{tabular}


Table 1. (continued)

\begin{tabular}{|c|c|}
\hline Resource & Practices \\
\hline $\begin{array}{l}\text { See also: Social and Emotional } \\
\text { Learning in Practice: A Toolkit of } \\
\text { Practical Strategies and Resources } \\
\text { (Walker, Olson, \& Herman, 2017) }\end{array}$ & $\begin{array}{l}\text { Equipping staff } \\
\text { - Building understanding and fluency of SEL } \\
\text { - Support SEL (or EQ) in practitioners } \\
\text { - Develop a culture of coaching } \\
\text { - Practice giving effective feedback } \\
\text { Creating the learning environment } \\
\text { - Spending time developing and using consistent routines } \\
\text { - Develop positive behavior expectations } \\
\text { Designing impactful learning experiences } \\
\text { - Sequenced } \\
\text { - Active } \\
\text { - Focused } \\
\text { - Explicit } \\
\text { Using data for improvement }\end{array}$ \\
\hline $\begin{array}{l}\text { Preparing youth to thrive: } \\
\text { Assessing SEL curriculum design } \\
\text { (David P. Weikart Center for Youth } \\
\text { Program Quality, 2016a) }\end{array}$ & $\begin{array}{l}\text { - Project content sequence } \\
\text { - SEL content sequence } \\
\text { - Safe space } \\
\text { - Responsive practices } \\
\text { - Supports for staff }\end{array}$ \\
\hline $\begin{array}{l}\text { Preparing youth to thrive: } \\
\text { Assessing SEL practices a (David P. } \\
\text { Weikart Center for Youth Program } \\
\text { Quality, 2016b) }\end{array}$ & \begin{tabular}{|} 
Staff practices \\
- Structure \\
- Modeling \\
- Facilitating \\
- Scaffolding \\
- Coaching \\
- Reflection
\end{tabular} \\
\hline
\end{tabular}


Table 1. (continued)

\begin{tabular}{|c|c|}
\hline Resource & Practices \\
\hline $\begin{array}{l}\text { The impact of after-school } \\
\text { programs that promote personal } \\
\text { and social skills (Durlak \& } \\
\text { Weissberg, 2007) } \\
\text { See also: Durlak, Weissberg, \& } \\
\text { Pachan (2010) }\end{array}$ & $\begin{array}{l}\text { Skill development activity approach ("SAFE") } \\
\text { - Sequenced } \\
\text { - Active } \\
\text { - Focused } \\
\text { - Explicit }\end{array}$ \\
\hline $\begin{array}{l}\text { SEL-focused after-school programs } \\
\text { (Hurd \& Deutsch, 2017) }\end{array}$ & $\begin{array}{l}\text { Effective staff practices for promoting SEL } \\
\text { - } \text { physical and psychological safety } \\
\text { - } \text { appropriate structure } \\
\text { - } \text { opportunities to belong } \\
\text { - } \quad \text { support for efficacy and mattering } \\
\text { - } \text { opportunities for skill building } \\
\text { - } \text { integration of family, school, and community efforts } \\
\text { - } \text { nurturance and support b } \\
\text { Youth-staff relationships } \\
\text { Supporting adult staff } \\
\text { - } \text { Recruit young people who are more likely to benefit from } \\
\text { participation } \\
\text { - Ensure multiple staff members have training in practices to promote } \\
\text { - SEL } \\
\text { - } \text { Offer collaborative planning time } \\
\text { Provide organizational supports (e.g., vacation, mental health } \\
\text { services, resources for professional learning) } \\
\text { - Support continuous improvement }\end{array}$ \\
\hline
\end{tabular}


Table 1. (continued)

\begin{tabular}{|c|c|}
\hline Resource & Practices \\
\hline $\begin{array}{l}\text { Promoting social and emotional } \\
\text { competencies in elementary school } \\
\text { (Jones, Barnes, Bailey, \& Doolittle, } \\
\text { 2017) }\end{array}$ & $\begin{array}{l}\text { (Recommendations) } \\
\text { - Focus more on teachers, classrooms } \\
\text { - Reflect development } \\
\text { - Rethink measurement }\end{array}$ \\
\hline $\begin{array}{l}\text { Navigating SEL from the inside out: } \\
\text { Looking inside and across } 25 \\
\text { leading SEL programs, a practical } \\
\text { resource for schools and OST } \\
\text { providers (Jones, Brush, et al., } \\
2017 \text { ) }\end{array}$ & $\begin{array}{l}\text { Key features of effective SEL programs: } \\
\text { - Occur within supportive contexts } \\
\text { - } \text { Build adult competencies } \\
\text { - } \text { Acknowledge features of the broader community context (i.e., } \\
\text { - Target a key behaviors and skills across multiple contexts } \\
\text { - Set reasonable goals } \\
\text { - Incorporate "SAFE" elements } \\
\text { Program components that support effectiveness and address } \\
\text { challenges: } \\
\text { - Activities beyond core lessons } \\
\text { - Climate and culture supports } \\
\text { - Applications to OST } \\
\text { - Adaptability to local context } \\
\text { - Professional development and training } \\
\text { - Support for implementation } \\
\text { - Tools to assess implementation and program outcomes } \\
\text { - Family and community engagement }\end{array}$ \\
\hline
\end{tabular}


Table 1. (continued)

\begin{tabular}{|c|c|}
\hline Resource & Practices \\
\hline $\begin{array}{l}\text { MHA Labs Skill Building Practice } \\
\text { Guide (MHA Labs, 2017) }\end{array}$ & $\begin{array}{l}\text { Planning and preparation } \\
\text { - } \text { Review core skills (building blocks) } \\
\text { - Identify skill expectations } \\
\text { - Identify performance evidence } \\
\text { - Identify potential feedback prompts } \\
\text { - Identify instructional strategies } \\
\text { - Examine results of planning process } \\
\text { Action and feedback } \\
\text { - Full engage youth in skills development process } \\
\text { - Make skills transparent } \\
\text { - Conduct the activity as planned } \\
\text { - Provide real-time skill-building feedback } \\
\text { Reflection and improvement } \\
\text { - Engage in reflection and continuous improvement } \\
\text { - Use appraisal tools }\end{array}$ \\
\hline
\end{tabular}


Table 1. (continued)

\begin{tabular}{|c|c|}
\hline Resource & Practices \\
\hline $\begin{array}{l}\text { Social and Emotional Learning in } \\
\text { Practice: A Toolkit of Practical } \\
\text { Strategies and Resources (Walker } \\
\text { et al., 2017) }\end{array}$ & $\begin{array}{l}\text { Equipping staff } \\
\text { - Understanding and fluency of SEL } \\
\text { - Individual SEL (or EQ) and cultural values } \\
\text { - Program sequencing to support skill-building } \\
\text { - Features of high quality programs that support SEL } \\
\text { Creating the learning environment } \\
\text { - Group and individual level expectations } \\
\text { - Effective feedback } \\
\text { - Integrated reflection } \\
\text { Designing impactful learning experiences } \\
\text { - Youth exploration of individual and community identity (Ways I Am) } \\
\text { - Sharing gratitude and communicate one's feelings (Ways of Feeling) } \\
\text { - Learn about empathy and setting group norms (Ways of Relating) } \\
\text { - Developing clear goals and working towards consensus (Ways of } \\
\text { - Doing) } \\
\text { Using data for improvement } \\
\text { - Using reflective activities to measure change over time } \\
\text { - Youth assessment and feedback for adults }\end{array}$ \\
\hline $\begin{array}{l}\text { Social and emotional learning } \\
\text { programs for adolescents (Yeager, } \\
\text { 2017) }\end{array}$ & $\begin{array}{l}\text { (Recommendations) } \\
\text { - Differentiate recommendations by age } \\
\text { - Find ways to make environments more respectful } \\
\text { - Think carefully about measurement }\end{array}$ \\
\hline
\end{tabular}

a SEL practices include key youth experiences in addition to staff practices. For the purpose of this review, we focused on the staff practices.

b The authors attribute this list to the 2002 publication by Eccles and Gootman, Community Programs to Promote Youth Development, and then elaborate upon each of those recommendations to discuss their application in promoting SEL in afterschool. 
As shown in Table 2, we then synthesized practices across resources to determine commonalities and synergies. This synthesis yielded eight SEL practices.

\section{Table 2. Crosswalk of SEL Practice Resources With Eight SEL Practices}

\begin{tabular}{|c|c|c|c|c|c|c|c|c|c|c|c|}
\hline & 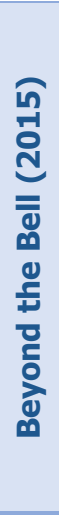 & 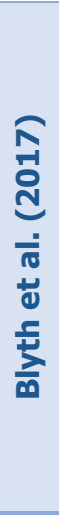 & 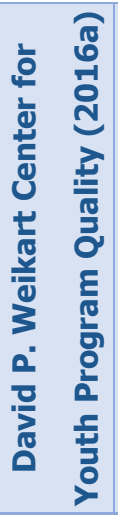 & 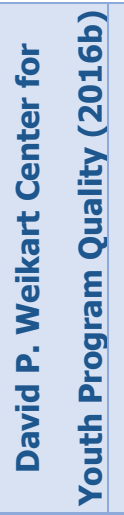 & 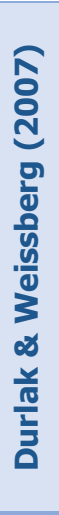 & 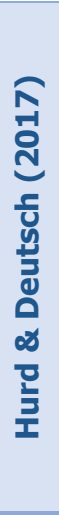 & 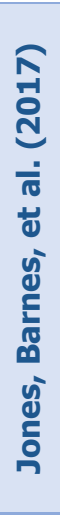 & 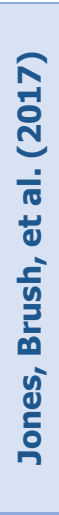 & 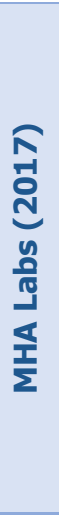 & 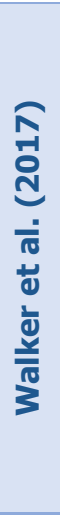 & 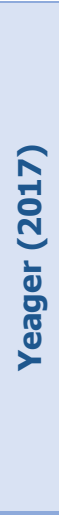 \\
\hline $\begin{array}{l}\text { Supporting adult social and emotional competence, health, and well- } \\
\text { being }\end{array}$ & 0 & 0 & 0 & & & 0 & 0 & 0 & & 0 & \\
\hline $\begin{array}{l}\text { Acknowledging the diverse characteristics of the community and other } \\
\text { learning contexts }\end{array}$ & 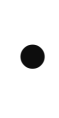 & 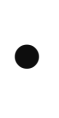 & & & & & & 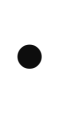 & & 0 & \\
\hline Planning for SEL programming & ○ & $\odot$ & ○ & & 0 & ○ & & 0 & ○ & 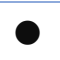 & \\
\hline Building in coaching and reflection for continuous improvement & ○ & $\odot$ & & ○ & & 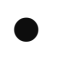 & 0 & 0 & 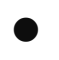 & $\odot$ & 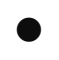 \\
\hline Creating a safe and supportive environment & ○ & 0 & ? & & & 0 & 0 & 0 & & 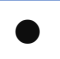 & 0 \\
\hline Supporting belonging and relationship-building & ○ & 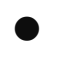 & ○ & & & 0 & 0 & 0 & & 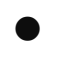 & \\
\hline $\begin{array}{l}\text { Understanding social and emotional development to support } \\
\text { competence-building }\end{array}$ & & & & & & & 0 & & & 0 & \\
\hline Providing opportunities for youth agency and engagement & ○ & $\odot$ & & ○ & & 0 & & & & 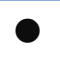 & \\
\hline
\end{tabular}


Our examination of the literature about these eight practices suggests that many of them are aligned with-if not completely grounded in-YD theory and practice. To highlight this alignment, we created a crosswalk of the eight practices with three seminal YD-focused publications: Eccles and Gootman's (2002) publication Community Programs to Promote Youth Development, the NAA CKCs (2011), and the instructional practices that underpin the Youth Program Quality Intervention and widely disseminated quality assessment tools (Smith et al., 2012). This crosswalk activity (Table 3 ) is illustrative in nature but highlights the connections between YD and SEL: YD and SEL practices are both designed to foster a safe and supportive environment, support relationship-building, be engaging, and provide opportunities for skillbuilding (Hurd \& Deutsch, 2017; Jones, Barnes, et al., 2017; Jones, Brush, et al., 2017).

\section{Table 3. Crosswalk of SEL Practices With Seminal Youth Development Resources}

\begin{tabular}{|c|c|c|c|}
\hline & $\begin{array}{c}\text { Eccles \& } \\
\text { Gootman (2002) }\end{array}$ & $\begin{array}{c}\text { National } \\
\text { AfterSchool } \\
\text { Association (2011) }\end{array}$ & $\begin{array}{l}\text { Smith, et al., } \\
\text { (2012) }\end{array}$ \\
\hline $\begin{array}{l}\text { Supporting adult social and emotional } \\
\text { competence, health, and well-being }\end{array}$ & & $\bullet$ & \\
\hline $\begin{array}{l}\text { Acknowledging the diverse characteristics of } \\
\text { the community and other learning contexts }\end{array}$ & ○ & $\bullet$ & - \\
\hline Planning for SEL programming & & - & $\mathbf{Q}^{\mathrm{a}}$ \\
\hline $\begin{array}{l}\text { Building in coaching and reflection for } \\
\text { continuous improvement }\end{array}$ & 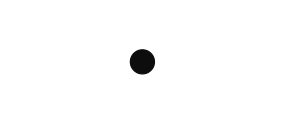 & ○ & $\mathbf{Q}^{\mathrm{a}}$ \\
\hline Creating a safe and supportive environment & - & - & - \\
\hline $\begin{array}{l}\text { Supporting belonging and relationship- } \\
\text { building }\end{array}$ & $\bullet$ & $\bullet$ & - \\
\hline $\begin{array}{l}\text { Understanding social and emotional } \\
\text { development to support competence- } \\
\text { building }\end{array}$ & $\bullet$ & $\bullet$ & \\
\hline $\begin{array}{l}\text { Providing opportunities for youth agency } \\
\text { and engagement }\end{array}$ & 0 & - & $\bullet$ \\
\hline
\end{tabular}

${ }^{a}$ Although not specific to SEL, the YPQI model emphasizes the role of assessment, planning, and improvement. 
While YD and SEL practices may be aligned, however, it is important to note that quality YD alone is not enough to support the development of key social and emotional competencies (Devaney \& Moroney, 2018; Shernoff, 2013). Rather, it is only through intentional SEL practice - of which, many YD principles should serve as the foundation-that the workforce will be able to create learning environments that support the development of social and emotional competencies (Blyth et al., 2017).

We believe there is a need to identify and describe the connection between what has been and what could be-that is, connecting YD as a foundation for intentional SEL. Moreover, we see that this creates a mechanism for supporting the OST workforce in their SEL practice. Rather than treating SEL as something new and different (which is conceivably much harder to do), we posit that OST professionals have the foundation (that is, YD) with which to focus on intentional SEL. In the sections that follow, we describe the eight SEL practices for OST, highlighting how YD principles and practices are foundational to intentional practices that foster SEL.

\section{Eight SEL Practices for the OST Workforce}

OST organizations and their leadership need to identify and be intentional about how they prepare staff to engage in SEL (Moroney \& Devaney, 2017). This may be accomplished through intentional hiring, preparation, and ongoing staff supports (Vandell \& Lao, 2016). Our examination of recent and widely disseminated SEL practice-focused resources elevated eight practices that are critical to the SEL process. To better understand the specific practices, we have broken them out into two categories: foundational organizational practices and programmatic practices that support social and emotional development.

\section{Organizational Practices that Support SEL}

The first four practices highlight organizational structures and processes that serve as a foundation for programmatic practices that guide the interactions between adults and youth.

\section{Supporting Adult Social and Emotional Competence, Health, and Well-Being}

There is evidence to suggest that adult social and emotional competence is essential to supporting both YD and SEL practice (see Schonert-Reichl, 2017). OST professionals who are socially and emotionally competent are better able to develop supportive relationships with 


\section{Intentional Social and Emotional Learning}

youth, create activities that build on the strengths of young people, and help them develop the basic social and emotional skills necessary to participate in programs (Jennings \& Greenberg, 2009). OST professionals should know and be able to articulate how their emotions, values, and beliefs inform their practice (American Institutes for Research, 2015). Understanding what the adults in the space "bring to the table" and how that may impact the youth they work with is essential to cultivating a learning environment that is supportive of and conducive to social and emotional growth (Blyth et al., 2017; Schonert-Reichl, 2017).

Relatedly, adult social and emotional health and well-being are related to healthy relationships, effective program management, and the effective implementation of SEL. Adult stress and burnout play a role in their social and emotional competence. Working with youth can be an incredibly rewarding, albeit stressful job with many demands. Adults who are overly stressed may not be able to connect with youth or effectively promote social and emotional practice. To facilitate the most positive experiences for youth, it is important to remember the social and emotional health of OST professionals working with them and on their behalf.

\section{Acknowledging the Diverse Characteristics of the Community and Other Learning Contexts} It is also critical that OST professionals understand and acknowledge diverse characteristics of the community and other learning contexts because cultural values and identity are directly connected to YD and SEL (Blyth et al., 2017; Walker et al. 2017). The relationship between cultural values and social and emotional skills is complex, as cultural values often influence which of these skills are most important for individual youth (Walker et al., 2017). Contextually relevant and culturally competent practice means that SEL will-and should!-look different for different youth. Culturally competent practices start with a foundation of (a) recognizing one's own cultural influences and biases, (b) knowledge of youth cultural backgrounds, (c) awareness of the broader social, economic, and political context, (d) ability and willingness to use culturally appropriate management strategies, and (e) a commitment to building caring communities (Blyth et al., 2017).

\section{Planning for SEL Programming}

Planning and intentionality are essential to effective implementation of SEL practices however, the mechanisms for supporting SEL practice may vary. Organizations can adopt a program, set of practices, curriculum, or framework that meets the needs of the youth and families served and then create a plan for implementation (American Institutes for Research, 2015; Walker et al., 2017). Using planning to align SEL with the school, families, and community is also 


\section{Intentional Social and Emotional Learning}

important. Many districts, schools, and after-school and expanded learning providers have goals that endeavor to align their SEL efforts, yet these efforts may not fully succeed because educators may use different language and operate within separate initiatives (Partnership for Children and Youth, 2017). By prioritizing SEL and integrating it into daily practice, OST professionals can begin to create conditions that foster opportunities for SEL. OST professionals should recognize and be able to capitalize on teachable moments that may occur during program time and employ strategies for supporting competence-building as it happens (a concept referred to as "taught and caught;" see Blyth, 2018).

\section{Building in Coaching and Reflection for Continuous Improvement}

As stated previously, SEL is a process and it is one that may, at times, require a level of vulnerability as OST professionals reflect on their own social and emotional competence, practices, areas of strength, and opportunities for growth. OST professionals will need to engage youth in an intentional process of reflection as well (David P. Weikart Center for Youth Program Quality, 2016b).

OST professionals will benefit when organizations adopt a culture of coaching and feedback that is not only supportive of professional growth but also adult well-being and social and emotional growth. The YD field has united around improvement systems that aim to improve quality at the point-of-service, and this also holds true for SEL efforts. By creating a culture in which OST professionals are collecting information in an ongoing manner and using it to drive decisions, everyone plays a role in supporting the program and making it better and more conducive to social and emotional growth. It is critical to include multiple stakeholders in those data collection efforts-from youth to their families to program staff-and to strive for multiple methods of data collection such as program observations, surveys, focus groups, and administrative data. OST professionals can and should continuously reflect on whether and how they are creating the right conditions for learning and development and how youth are developing key social and emotional competencies.

\section{Programmatic Practices that Support SEL}

While the first four practices focus on what organizations can do to support SEL, the next four highlight what the OST professional can do to support SEL. Although we have articulated four separate practices in the sections that follow, it is important to note that many of these practices overlap and may (and should) happen concurrently. 


\section{Intentional Social and Emotional Learning}

\section{Creating a Safe and Supportive Environment}

Social and emotional development does not happen in isolation. Rather, it happens when OST professionals understand and can create an environment that is safe, both physically and psychologically (Jones, Barnes, et al., 2017; Jones, Brush, et al., 2017; Schonert-Reichl, 2017). It is only when young people feel safe and secure that they may have the capacity to engage in the learning process. Given the vulnerable nature of personal and social development, the environment and conditions for learning are even more critical for SEL. OST professionals therefore need to understand how to develop and implement policies and practices that ensure safe, fair, and equitable treatment for all youth.

Once a safe environment is established, OST professionals should know and be able to create an environment that is warm and welcoming (American Institutes for Research, 2015; David P. Weikart Center for Youth Program Quality, 2016b; Schonert-Reichl, 2017). This is an element that is fundamental to YD practice but is sometimes overlooked in OST SEL practice. Many OST professionals are familiar with strategies and activities that are fun and can create a welcoming space-trust circles, ice breaker activities, emotion reflections and discussions, to name a fewbut they may overlook the ways in which these mechanisms can also be used to foster intentional SEL, by helping young people practice communication, active listening, appreciation for similarities and differences, and collaboration.

Likewise, youth need to know that OST professionals care about them and it is essential for OST professionals to understand that verbal communication and nonverbal body language matters. Young people learn from the adults that surround them, from the ways in which program staff speak to them to how they interact with other adults; staff language is critical in that they are modeling for youth as well as creating (or detracting from) a warm and welcoming space to grow and develop (Blyth et al., 2017).

OST professionals should also know and be able to ensure consistency through routines and positive behavior expectations (Blyth et al., 2017). This may include, for example, codeveloping guidelines and adopting shared norms that youth and adults can agree on. When issues arise, adults and youth, together, can reflect on those norms and discuss problemsolving strategies. Accordingly, OST professionals must understand logical consequences or, if developmentally appropriate, understand how to encourage youth to suggest logical consequences when a norm or a rule is broken. Encouraging youth to make connections between the choices they make, and potential outcomes or consequences is essential to 


\section{Intentional Social and Emotional Learning}

developing key social and emotional competencies. Finally, OST professionals can also create a culture that supports making mistakes and thinking "outside the box." Young people will learn best from their mistakes when they are free to make them. Using mistakes as a learning opportunity and encouraging persistence is key.

\section{Supporting Belonging and Relationship-Building}

OST professionals need support to be able to nurture developing relationships to sustain them, so it is critical that OST professionals can support a young person's sense of belonging and build relationships (Jones, Barnes, et al., 2017). ${ }^{1}$ Relationships are essential to YD programs (see Eccles \& Gootman, 2002) because they support a safe and supportive environment and, ultimately, youth engagement. However they are also paramount to intentional SEL because the act of engaging in successful and positive relationships is often seen as an essential social and emotional skill that young people can and should develop.

Because young people experience many types of relationships in OST-youth with staff, youth with each other, staff with staff, youth developing their own sense of identity and therefore relationship with themselves-OST professionals must be able to cultivate relationships effectively because, in doing so, they are teaching young people why and how relationships work. To that end, it is also critical that OST professionals identify seemingly innocuous structures or practices that may unintentionally promote exclusion and restructure them to promote inclusion and relationship-building instead (Jones, Barnes, et al., 2017).

Finally, OST professionals need the skills and strategies to engage with youth while authentically learning about their interests and their lived experience (which may also include engaging families and other members of the community). This enables OST professionals to use youth interest to guide activities and align competence-building accordingly. This not only fosters a sense of belonging and inclusion, but it also promotes youth engagement and boosts competence-building efforts by ensuring their relevance.

\footnotetext{
${ }^{1}$ While relationships are often seen as a critical component of creating a safe and supportive environment, our review of SEL practice resources elevated these two concepts separately, suggesting the significance of each practice individually.
} 


\section{Intentional Social and Emotional Learning}

Understanding Social and Emotional Development to Effectively Support Social and Emotional

\section{Competence-Building}

OST professionals who work with youth must understand social and emotional development and what developmentally appropriate practice (DAP) looks like for the specific age/grade range of young people they are working with (Blyth et al., 2017; Schonert-Reichl, 2017). This knowledge should underpin all efforts—-both explicit and embedded-around competence-building. It is worth noting that many states have now developed SEL standards for learning that specify what young people should know and be able to do at different developmental periods (Dusenbury, Dermody, \& Weissberg, 2018). Although the standards are intended for use in schools, DAP does not change based on setting and this may be a useful resource for OST professionals as they aim to implement intentional SEL.

In addition to DAP, Durlak and Weissberg (2007) defined the now well-established acronym "SAFE" to articulate the importance of engaging in skill-building that is sequenced, active, focused, and explicit. OST professionals should be able to sequence each activity so that there is a clear and logical flow and that each activity scaffolds (i.e., builds upon each other) over the course of the program cycle (David P. Weikart Center for Youth Program Quality, 2016a). Understanding developmentally appropriate SEL practice will also ensure staff are able to scaffold activities appropriately, providing just the right amount of support for youth to learn, and increasing the level of challenge as they continue mastery. This notion of scaffolded programming is evident in many YD program quality resources that focus on skill-building generally, and those same concepts should apply to intentional SEL as well.

OST professionals should also understand and be able to design activities and plan programming that is active and engaging (David P. Weikart Center for Youth Program Quality, 2016a; Durlak \& Weissberg, 2007; Jones, Brush, et al., 2017). Activities should be interactive and hands-on, embedding competence-building into everyday practice when possible. SEL practice expands when OST professionals understand when and how to capitalize on teachable moments, recognizing when young people demonstrate social and emotional competencies effectively, noticing when they may need support, engaging in an ongoing process of modeling competencies for youth, and encouraging youth to practice while providing feedback, and inthe-moment coaching (Blyth et al., 2017; Newman, Dymnicki, Fergus, Weissberg, \& Osher, 2018). 
Providing Opportunities for Youth Agency and Engagement in Learning and Development The concepts of voice, choice, leadership, and agency are strongholds of the YD principles and are often employed by OST professionals with the goal of ensuring that young people are heard and know that they are valued. Hearing from young people serves to improve any OST program-SEL-focused or otherwise-by ensuring that programming reflects their experience, wants, and needs.

As these concepts relate to SEL, however, OST professionals can go deeper to support social and emotional competence-building. Encouraging youth voice, choice, and leadership provides youth with an opportunity to explicitly understand and then practice critical social and emotional competencies such as self-awareness and self-management, effective communication, and active listening. When youth share their voice and see change, OST professionals can work with youth so they learn not only that their voice has value (essential to YD practice) but also that there are effective (or less effective) ways to communicate (essential to SEL practice). In addition, youth learn the critical skill of decision-making when they have opportunities to make choices and they see the reality of cause and effect (two critical social and emotional skills). When engaging in intentional SEL, OST professionals should understand and be able to provide and help youth make choices about both process and content, in a developmentally and authentic way; that may lead to a discussion about those choices and their impact, which can help youth learn to make responsible decisions (yet another social and emotional skill).

\section{Recommendations: Where Do We Go from Here?}

As the OST field embraces SEL, understanding what SEL is and what it can look like in practice is critical. We have taken preliminary steps to do that here, by reviewing the myriad resources that are currently available to elevate eight SEL practices. We have also suggested that a second mechanism for effectively supporting the OST workforce lies in reframing the discussion around SEL, moving away from the notion that SEL is something new and refocusing on intentional SEL that logically builds from the YD foundation that already underpins quality OST programming.

The synthesis presented here is only the first step in supporting the OST workforce in their efforts to engage in intentional SEL. There is still much to be learned about the barriers and facilitators of intentional SEL and the most effective methods for providing professional learning for an OST workforce that has historically had limited opportunities for training. At a high level, 


\section{Intentional Social and Emotional Learning}

we recommend six steps that OST leaders can take to support the workforce in implementing the intentional SEL practices described in this article:

1. Reflect on current YD practice to determine whether, where, and how programs and staff can incorporate intentional SEL practice.

2. Foster a climate and culture that is supportive of social and emotional growth, not only for youth but for OST professionals as well.

3. Align efforts to support SEL: Conduct a needs assessment, create an asset map, or engage in other assessments to align practices and supports with youth, families, and the community. This helps OST professionals understand context, provide programming that supports growth and development, and engage with families and community members in a way that reflects their values, acknowledges their lived experiences, and works for them.

4. Plan for SEL: Ensure that appropriate time and resources are available for continuous professional learning, including integrating SEL topics into meetings and providing resource materials for all OST professionals.

5. Engage in professional learning: Provide training for practitioners in evidence-based approaches to SEL and make the training opportunities available to OST professionals at a variety of levels within the staffing structure. (This fosters conditions where OST professionals are able to support each other as they learn new competencies, gain new knowledge, and implement it across a variety of settings.)

6. Create structures for ongoing reflection and assessment that support ongoing improvement: Implement routine practices so OST professionals can set goals and incorporate use of a self-reflection tool into daily programming, developing individual and group action plans to work toward goals.

As we continue to grow and evolve as a field of YD-focused OST professionals-many of whom are on a path toward intentional SEL-the need to support the professionals engaged in this work becomes increasingly clear. SEL for youth begins with the adults-be it from organizational structures to professional learning, or from recognizing where, when, and how learning happens to intentionally creating the conditions we all need to grow and develop. Now comes the essential work of continuing to create and make available resources, materials, and 
Journal of Youth Development | http://jyd.pitt.edu/ | Vol. 15 Issue 1 DOI 10.5195/jyd.2020.807

Intentional Social and Emotional Learning

opportunities for professional learning that strengthen the workforce, so they can effectively engage in the SEL process.

\section{References}

American Institutes for Research. (2015). Social and emotional learning practices: A self-reflection tool for afterschool staff. Chicago, IL: Author. http://www.air.org/resource/social-and-emotionallearning-practices-self-reflection-tool-afterschool-staff

American Institutes for Research. (2017). 50 state afterschool network: Scan of quality systems. Chicago, IL: Author.

https://www.air.org/sites/default/files/SAN\%20Scan\%20of\%20Quality OCTOBER\%202017\%20U pdate.pdf

American Institutes for Research. (2019). Ready to assess. Chicago, IL: Author.

https://www.air.org/resource/are-you-ready-assess-social-and-emotional-learning-anddevelopment-second-edition

Aspen Institute National Commission on Social, Emotional, \& Academic Development. (2018). From a nation at risk to a nation at hope: Recommendations from the national commission on social, emotional, \& academic development. http://nationathope.org/wpcontent/uploads/2018 aspen final-report full webversion.pdf

Beyond the Bell. (2015). Social and emotional learning practices: A self-reflection tool for afterschool staff. Chicago: American Institutes for Research. https://www.air.org/resource/social-andemotional-learning-practices-self-reflection-tool-afterschool-staff

Berg, J., Osher, D., Same, M. R., Nolan, E., Benson, D., \& Jacobs, N. (2017). Identifying, defining, and measuring social and emotional competencies. Washington, DC: American Institutes for Research. https://www.air.org/sites/default/files/downloads/report/Identifying-Defining-andMeasuring-Social-and-Emotional-Competencies-December-2017-rev.pdf

Blyth, D. A. (2018). The challenges of blending youth development and social and emotional learning: Getting more intentional about how competencies are both caught and taught in out-of-school time. In E. Devaney \& D. A. Moroney (Eds.), Social and emotional learning in out-of-school time: Foundations and futures (pp. 15-34). Charlotte, NC: Information Age.

Blyth, D., Olson, B., \& Walker, K. (2017). Intentional practices to support social and emotional learning. Saint Paul: University of Minnesota Extension. https://conservancy.umn.edu/bitstream/handle/11299/195178/issue-brief-intentional-practicesto-support-sel.pdf?sequence $=1 \&$ isAllowed $=y$ 
Journal of Youth Development | http://jyd.pitt.edu/ | Vol. 15 Issue 1 DOI 10.5195/jyd.2020.807

Intentional Social and Emotional Learning

Cole, P. (2011). Building an afterschool workforce: Regulations and beyond. Afterschool Matters, 13, 12-

21. https://www.niost.org/pdf/afterschoolmatters/asm_2011_13 spring/asm_2011_13 spring2.pdf

Collaborative for Academic, Social, and Emotional Learning. (n.d.) Social and Emotional Learning. https://casel.org/overview-sel/

David P. Weikart Center for Youth Program Quality. (2016a). Preparing youth to thrive: Assessing SEL curriculum design. Ypsilanti, MI: Author. Retrieved from www.selpractices.org

David P. Weikart Center for Youth Program Quality. (2016b). Preparing youth to thrive: Assessing SEL practices. Ypsilanti, MI: Author. Retrieved from www.selpractices.org

DePaoli, J. L., Atwell, M. N., \& Bridgeland, J. (2017). Ready to lead: A national principal survey on how social and emotional learning can prepare children and transform schools. Chicago, IL: Collaborative for Academic, Social, and Emotional Learning. http://www.casel.org/wpcontent/uploads/2017/11/ReadyToLead FINAL.pdf

Devaney E., \& Moroney D. A. (Eds., 2018). Social and emotional learning in out-of-school time: Foundations and futures. Charlotte, NC: Information Age.

Durlak, J. A., \& Weissberg, R. P. (2007). The impact of after-school programs that promote personal and social skills. Chicago, IL: Collaborative for Academic, Social, and Emotional Learning.

Durlak, J. A., Weissberg, R. P., \& Pachan, M. (2010). A meta-analysis of after-school programs that seek to promote personal and social skills in children and adolescents. American Journal of Community Psychology, 45, 294-309. https://doi.org/10.1007/s10464-010-9300-6

Dusenbury, L., Dermody, C., \& Weissberg, R. (September 2018). State scorecard scan. Chicago, IL: Collaborative for Academic, Social, and Emotional Learning. https://casel.org/wpcontent/uploads/2018/09/csi-scorecard-sept2018.pdf

Eccles, J., \& Gootman, J. A. (Eds.). (2002). Community programs to promote youth development. Institute of Medicine; National Research Council; Division of Behavioral and Social Sciences and Education; Board on Children, Youth, and Families; Committee on Community-Level Programs for Youth. Washington, DC: National Academies Press.

Every Hour Counts. (2014). Every hour counts measurement framework: How to measure success in expanded learning systems. https://static1.squarespace.com/static/5b199ed585ede1153ef29e8a/t/5b19a09e2b6a28c655798a 25/1528406174521/Every+Hour+Counts+Measurement+Framework.pdf

Hurd, N., \& Deutsch, N. (2017). SEL-focused after-school programs. The Future of Children, 271), 95115. 
Journal of Youth Development | http://jyd.pitt.edu/ | Vol. 15 Issue 1 DOI 10.5195/jyd.2020.807 Intentional Social and Emotional Learning

Jennings, P. A., \& Greenberg, M.T. (2009). The prosocial classroom: Teacher social and emotional competence in relation to student and classroom outcomes. Review of Educational Research, 79, 491-525. https://doi.org/10.3102/0034654308325693

Jones, S.M., Barnes, S.P., Bailey, R., \& Doolittle, E.J. (2017). Promoting social and emotional competencies in elementary school. The Future of Children, $2 \pi 1), 49-72$.

Jones, S.M., Brush, K., Bailey, R., Brion-Meisels, G., McIntyre, J., Kahn, J., et al. (2017). Navigating SEL from the inside out: Looking inside and across 25 leading SEL programs, a practical resource for schools and OST providers. Cambridge, MA: Harvard Graduate School of Education. http://www.wallacefoundation.org/knowledge-center/Documents/Navigating-Social-andEmotional-Learning-from-the-Inside-Out.pdf

Jones, S., \& Doolittle, E. (2017). Social and emotional learning: Introducing the issue. The Future of Children, 2オ1), 3-11.

Kataoka, S., \& Vandell, D. L. (2013). Quality of afterschool activities and relative change in adolescent functioning over two years. Applied Developmental Psychology, 173), 1-12. https://doi.org/10.1080/10888691.2013.804375

Mahoney, J. L., \& Warner, G. (2014). Issue editors' notes. New Directions for Youth Development, 2014(144), 1-10.

McElvain, C., Moroney, D., Devaney, E., Singer, J., \& Newman, J. (2014). Beyond the bell: A toolkit for creating effective afterschool and expanded learning programs ( $4^{\text {th }}$ ed.). Washington, DC: American Institutes for Research.

McCombs, J., Whitaker, A., \& Yoo, P. (2017). The value of out-of-school time programs. Santa Monica, CA: RAND. https://www.wallacefoundation.org/knowledge-center/Documents/The-Value-of-Outof-School-Time-Programs.pdf

MHA Labs. (2017). MHA Labs practice guide. Available from http://mhalabs.org/skill-building-practice/ Moroney, D. A. (2016). The readiness of the out-of-school time workforce to intentionally support participants' social and emotional development: A review of the literature and future directions. Washington, DC: National Academies of Sciences.

Moroney, D. A. \& Devaney, E. (2017). Ready to implement? How the out-of-school time workforce can support character development through social and emotional learning: A review of the literature and future directions. Journal of Character Education, 13(1), 67-89.

Moroney, D., Singer, J., \& Newman, J. (2016, March) The power of SEL. Meeting presentation at the National AfterSchool Association Convention 2016, Orlando, FL.

National AfterSchool Association. (2011). Core knowledge and competencies for afterschool and youth development professionals. Oakton, VA: Author. 
Nee, J., Howe, P., Schmidt, C., \& Cole, P. (2006). Understanding the afterschool workforce: Opportunities and challenges for an emerging profession. Houston, TX: National Afterschool Association for Cornerstones for Kids.

Newman, J., Dymnicki, A., Fergus, E., Weissberg, R., \& Osher, D. (2018). Social and emotional learning matters. In D. Osher, D.A. Moroney, \& S. Williamson (Eds.), Creating safe, equitable, engaging schools: A comprehensive, evidence-based approach to supporting students (pp. 213-222). Cambridge, Mass: Harvard Education Press.

Partnership for Children and Youth. (2017). Finding common ground: Connecting social-emotional learning during and beyond the school day. Oakland: Author. https://static1.squarespace.com/static/59f76b95268b96985343bb62/t/59fca05be4966b20211399 66/1509728349225/Finding-Common-Ground Connecting-SEL-to-K12-and-ELT.pdf

Schonert-Reichl, K. (2017). Social and emotional learning and teachers. The Future of Children, 271), 137-155.

Shernoff, D. J. (2013). Advancing responsible adolescent development. Optimal learning environments to promote student engagement. New York, NY: Springer. https://link.springer.com/content/pdf/10.1007/978-1-4614-7089-2.pdf

Smith, C., Akiva, T., Sugar, S. A., Lo, Y.-J., Frank, K. A., Peck, S. C., \& Cortina, K. (2012). Continuous quality improvement in afterschool settings: Impact findings from the youth program quality intervention study. Ypsilanti, MI: Forum for Youth Investment.

Starr, E., \& Gannett, E. (2017). The state of professional development: Past, present, and future. In H. Malone \& T. Donahue (Eds.), The Growing Out-of-School Time Field: Past, Present, and Future (195-210). Information Age.

Stone, B., Garza, P., \& Borden, L. (2004). Wingspread Conference Proceedings: Attracting, developing, and retaining youth workers for the next generation. https://cyfar.org/sites/default/files/Stone\%202004.pdf

Vandell, D. L., \& Lao, J. (2016). Building and retaining high quality professional staff for extended education programs. International Journal for Research on Extended Education, 4, 52-64. https://doi.org/10.3224/ijree.v4i1.24775

Vandell, D. L., Larson, R. W., Mahoney, J. L., \& Watts, T. W. (2015). Children's organized activities. In M. H. Bornstein and T. Leventhal (Eds.), Handbook of child psychology and developmental science, Volume 4: Ecological settings and processes in developmental systems (7 $7^{\text {th }}$ ed., pp. 305-344). Editor-in-chief: R. M. Lerner. Hoboken, NJ: Wiley.

Vandell, D., Reisner, E. R., \& Pierce, K. (2007). Outcomes linked to high-quality afterschool programs: Longitudinal findings from the study of promising afterschool programs. Irvine: University of California, \& Washington, DC: Policy Studies Associates. 
Journal of Youth Development | http://jyd.pitt.edu/ | Vol. 15 Issue 1 DOI 10.5195/jyd.2020.807 Intentional Social and Emotional Learning

Walker, K., Olson, B., \& Herman, M. (2017). Social and emotional learning in practice: $A$ toolkit of practical strategies and resources. Saint Paul: University of Minnesota Extension. Available at https://extension.umn.edu/what-youth-development/sel-toolkit

Warner, G., Ham, H., \& Fenton, M. (2017). Core competencies for the OST field. In H. Malone \& T. Donahue (Eds.), The growing out-of-school time field: Past, present, and future (pp. 103-113). Charlotte, NC: Information Age.

Yeager, D.S. (2017). Social and emotional learning programs for adolescents. The Future of Children, $2 \pi(1), 73-94$.

Yohalem, N. \& Wilson-Ahlstrom, A., with Fischer, S. \& Shinn, M. (2009, January). Measuring youth program quality: A guide to assessment tools ( $2^{\text {nd }}$ ed.). Washington, D.C.: The Forum for Youth Investment. 